WIESŁAW OSTROWSKI, IZABELA KARSZNIA

University of Warsaw, Faculty of Geography and Regional Studies

Department of Geoinformatics, Cartography and Remote Sensing

Warsaw, Poland

wieslawostrow@gmail.com, i.karsznia@uw.edu.pl

TOMASZ PANECKI

Institute of History, Polish Academy of Sciences

Department of Historical Atlas

Warsaw, Poland

tpanecki@uw.edu.pl

\title{
Comparative analysis of a characterization of the built-up area and settlement network on Polish topographic maps from the 19th, 20th and 21st centuries*
}

\begin{abstract}
Built-up area is a particularly important element of the content of topographic maps. Its presentation changes significantly when map scales are reduced, due to both conceptual and graphic generalization. What is more, historically, changes in the depiction of built-up area were consequences of changes in the intended use of topographic maps, development of technology and changes in the cultural landscape, of which the built-up area is an important component.

The authors describe the method of presentation of built-up areas on six Polish topographic maps or series of maps. The above-mentioned maps include the following:

- Topograficzna Karta Królestwa Polskiego (Topographic Map of the Polish Kingdom) at the scale of 1:126,000 developed in 1822-1843;

- topographic maps of the Polish Military Geographical Institute (MGI) at the scales of 1:25,000 and 1:100,000, published in 1930s;

- a series of military maps (or military-civilian maps) at the scales of 1:10,000,1:25,000, 1:50,000 and 1:100,000, developed in 1956-1989, in accordance with the instruction for developing Soviet maps;

- a series of civilian maps at the scales of 1:10,000, 1:25,000, 1:50,000 and 1:100,000 developed after 1995.

The basis for a quantitative comparison of the content of the maps was the number of categories of objects (identifications) which constitute part of built-up area and are presented on individual maps as symbols, as well as the number of characteristics represented by these symbols. These characteristics are divided into two basic types: functional characteristics and physiognomic characteristics.

The analysis shows that military maps issued after the Second World War differ from the civilian maps, as they contain a much larger share of physiognomic characteristics, which is caused mainly from the fact that the vast majority of military maps distinguish between wooden and brick buildings. This difference was to large extent already noticeable among the oldest of the analysed maps - the Quartermaster's Map and nineteenth-century Russian maps, which were partly modelled on the Quartermaster's Map, and later also Soviet maps. Due to political reasons, the model of these Soviet maps was later adopted for the development of post-war Polish military maps. Out of all maps drawn up by military services, the inter-war MGI map serves special attention, as it was modelled on German maps. The main difference between military and civilian maps is foremost the fact that civilian maps include more functional characteristics of buildings and take into consideration new physiognomic characteristics related to residential development (compact, dense, multifamily dwellings, single family dwellings).

The analysed maps include not only the characteristics of buildings and built-up area, but also information on the features of the town - population size, number of village houses and the administrative function.
\end{abstract}

Keywords: comparative analysis, topographic map, built-up area, buildings, locality

\footnotetext{
* The works on the database have been founded within the "Ontological foundations of the historical GIS" (Pol. Ontologiczne podstawy budowy historycznych systemów informacji geograficznej), contract no. 2bH15021683, financed by Narodowy Program Rozwoju Humanistyki (National Programme of the Development of Humanistics) under Bogumił Szady of Tadeusz Manteuffel Institute of History, Polish Academy of Sciences.
} 


\section{Introduction}

Built-up area, together with the transport network (especially road network), are some of the most important and most frequently analysed categories of topographic map content. The scope of application of this category, which is usually assumed to be the scale of $1: 200,000$ or $1: 250,000$, is at the same time the conventional demarcation line between topographic and general maps (J. Neuman 1972). On general maps, the concept of built-up area is replaced with a more general concept of localities usually presented with geometric symbols, differentiated on the basis of the number of their inhabitants. Although larger towns are presented with a contour, which represents a generalized scope of the built-up area, but this scope is treated as a spatial feature of the locality rather than the built-up area. The combination of these two ways of presentation on medium-scale maps (symbol against the background of outline) allows to present both a broader range of spatial characteristics of the locality (location, shape, range) and statistical characteristics (number of population).

It is worth noting that the meaning of the term "built-up area" is not entirely unambiguous. In the modern Polish Database of Topographic Objects (DBTO), the built-up area is defined as areas "...consisting of residential and industrial buildings, warehouses, and buildings used for agricultural production etc., together with small areas and facilities functionally connected with the buildings, such as courtyards, squares, passageways, crossings, backyard playgrounds, etc." (Rozporządzenie... 2011, p. 79). All kinds of buildings and their adjacent areas which are functionally associated with them (e.g. industrial and storage areas) constitute therefore the integral component of the built-up area. However, there can be some doubts whether the category of "built-up area" includes also ruined buildings, windmills, tower-like buildings, and greenhouses. Still, the afore-mentioned objects will be included in the built-up area. The instructions of Polish post-war military topographic maps, as well as civil maps which were based on them within the "1965" coordinate system, used the too-broad term "housing estate" (osiedle), including "denselydeveloped housing estate" (osiedle o zwartej zabudowie), instead of the term "built-up area".

\section{Presentation of built-up area on topographic maps}

As already mentioned, built-up area is a particularly important element of the content of topographic maps, which was confirmed by surveys carried out among map users (D. Schmid 1987). At the same time, it is the element whose presentation in the succession of scales from $1: 10,000$ to $1: 100,000$ undergoes most significant and diverse changes, due to both conceptual and graphic generalization. This is due to the character of the built-up area, whose degree of spatial concentration is very diverse (compact, dense, dispersed development), which is, in turn, difficult to present, as the area gets significantly smaller and the scale of maps' decreases. What is more, built-up area is also a very diverse category and its physiognomic and functional features, as well as the weight they are assigned, can be determined and estimated in different ways. Therefore, it has been widely believed for a long time that generalization of buildings is particularly difficult and subjective (E. Imhof 1936/37, R. Schmid 1966). "As is apparent from cartographic practice, although we can say that it is a fairly commonly held opinion that topographic maps are a relatively objective image of the Earth's surface in comparison to thematic maps, this statement rings least true when we consider the presentation of built-up areas on medium- and even small-scale topographic maps, where the degree of the subjectivism of the generalization of this element of the map content is by far the largest" (W. Ostrowski 2008). The method of generalization and presentation of the built-up area was not based on precisely formulated rules, but has been created in the course of many years of cartographic practice.

In addition, changes in the method of generalization and presentation of buildings, and in particular changes in the selection and scope of its characteristics, have been caused by several objective reasons. The first reason was the change of the basic purpose of topographic maps. Until 1950s, and in the countries of Central and Eastern Europe until the end of 1980s, the choice of characteristics of buildings and built-up areas depicted on maps was primarily determined by the needs of the army, as military services were the creator of the very concept of topographic maps, as well as their main or 
one of main developers and users. Diverse needs of civilian map users began to be taken into account in many countries, Poland included, only in the last twenty-five years of the last century.

Technological development was the second significant reason for the changes in both the presentation method and the scope of characteristics of built-up areas depicted on topographic maps. New technologies made it possible to use full multi-colour printing, which allowed for making line drawings, which has dominated in topographic maps for centuries and was used to depict symbols, surface outlines and patters noticeably richer, with only supplementary use of coloured surfaces. In consequence, maps become significantly more legible and began to include more characteristics of both individual buildings and built-up areas.

Historical changes, foremost emergence of block of flats, high-rise buildings, holiday settlements and shopping centres, which have occurred in urban areas in the last century constitute the third reason for changes in the selection of building characteristics, particularly important in urban areas.

Characteristics of built-up areas are depicted on maps with the help of a great variety of means, visual variables, and presentation methods. In addition to the two basic methods - the range method and the quantitative pictoral symbols use the vast majority of graphical variables a wide range of labels (including names, much less often, names of specific types of objects), especially explanatory abbreviations, which usually define the function of a given building or building complex, are used to provide characterization of buildings, built-up areas and localities.

Topographic maps present two basic types of characteristics of buildings and built-up areas: functional (residential, industrial and service buildings) and physiognomic (height, capacity, characteristic shape of buildings, material, and density of development). Physiognomic characteristics can also include the features of intensity of land development (height of buildings, density of development), which distinguished by some authors (e.g. S. Liszewski 1978). The distinction of these two types of characteristics will be the basis for comparing the presentation of built-up areas on Polish topographic maps.
Only graphical variables (usually colour, valour and shape) are used to characterize physiognomy, while, in the case of functional characteristics, graphical variables are usually used only for the presentation of general functions (e.g. industrial buildings, and public buildings). Both symbols (e.g. forester's lodge, inn) and, more frequently, explanatory abbreviations (e.g. "szk." for school, "szpit." for hospital, and "brow." for brewery) are used when more detailed functions are to be included on the map.

\section{Selection of maps for analysis}

The presentation and method of generalization of built-up area largely depends on the scale of a given map, to a bigger extend than in the case of other elements of topographic maps. On 1:10,000 maps, built-up areas are presented by means of outlines, and more rarely with symbols representing individual buildings. As the scale of the map decreases $(1: 25,000$, $1: 50,000,1: 100,000)$, the symbols of individual buildings begin to be gradually replaced by areal symbols indicating built-up areas.

The basis for the quantitative comparison was the number of categories of objects classified as part of the built-up area and presented on individual maps. This comparison will not take into account the detailed characteristics of objects, e.g. explanatory abbreviations, as the number of possible abbreviation types has usually not been strictly defined (other abbreviations may be used in addition to those mentioned in the legend or in the instructions). It should be remembered, however, that on large scale maps, especially $1: 10,000$ ones, the types of some objects (most often shown in the outline) are explained with appropriate abbreviations, and that on smaller-scale maps these objects are represented by symbols (e.g. sewage treatment plants, railway stations) instead of abbreviations. This limits somewhat the level of comparability of maps with different scales, and thus, we will carry out a detailed comparative analysis of presentation of built-up areas separately for maps with the following scales $1: 10,000,1: 25,000,1: 50,000,1: 100,000$, and 1:126,000.

Twelve Polish topographic maps developed and published in the last two hundred years were selected for the comparative analysis of characteristics of build-up area. They are: 
- Topographic Map of the Polish Kingdom (the so-called Quartermaster's Map) developed at the scale of $1: 126,000$ in $1822-1843$ by the Polish Army's Quartermaster's Headquarters (until 1830) and the Corps of the Military Topographers of the Russian army (after 1830);

- topographic maps of the Polish Military Geographical Institute (MGI): a detailed 1:25,000 map and a tactical 1:100,000 map issued in its final version in the 1930s;

- a 1:10,000 map in the "1942" coordinate system developed jointly by the Polish Army Topographc Service and Head Office of Geodesy and Cartography in 1956-1974, in accordance with the instructions developed in the army on the basis of Soviet instructions, which, in consequence, will be considered as one of the military maps in any further considerations;

- military topographic maps of the Polish Army Topographic Service at the scales of 1:25,000, $1: 50,000$, and $1: 100,000$, in the "1942" coordinate system, developed in 1966-1989, also on the basis of the model of Soviet maps;

- civilian topographic maps at the scales of $1: 10,000$ and $1: 50,000$, in the "1992" coordinate system, issued by the Head Office of Geodesy and Cartography in 1995-2002;

- maps at the scales of $1: 10,000,1: 25,000$, $1: 50,000$ and $1: 100,000$, developed on the basis of the Database of Topographic Objects (DBTO10k).

\section{Maps at the scale of $1: 10,000$}

From the three analysed $1: 10,000$ topographical maps, the military map contained the largest number of categories of content related to built-up areas - it contains 26 categories, while the map created in the "1992" coordinate system and the one developed on the basis of DBTO both contain only eighteen. Additionally, the military map takes into account more building characteristics - 39 features, whereas the other two civilian-use maps depict only 29 and $28^{2}$.

\footnotetext{
2 The number of features usually exceeds by far the number of categories contained in the legend or in the map's development instructions. For example, the category "fire resistant chapel" contains two features: a functional (chapel) and physiognomic (fireproof) one. The term "water tower" also includes both functional (referring to its service function) and physiognomic (indicating a tower-shaped structure) characteristics.
}

An important feature of the military 1:10,000 map is the fact that it presents as many as seven functional categories of buildings (residential, non-residential, churches, chapels, mosques, industrial plants, and windmills) and the fact that they are also divided into fireproof and non fire resistant buildings (or in the case of windmills for brick and wooden constructions), which is an important feature from the military point of view (fig. 1). The map allowed for orientation in the field, which was very important for the army, so distinctive residential and non-residential buildings were clearly marked (Wzory i objaśnienia..., 1989). In total, 59\% of the characteristics of buildings relate to their physiognomy, and only $41 \%$ to their functions.

The number of physiognomic characteristics was reduced by half on the 1:10,000 map in the "1992" coordinate system, getting rid of the differentiation between fireproof and non fire resistant buildings, as well as brick, wooden, and distinctive ones. Instead of using the "distinctive buildings" category, the map presents tall buildings which have eleven or more floors (residential and public buildings) or are more than thirty-meter-high (industrial buildings). The division of buildings into multi-family and single family dwellings is the second way of introducing divisions on the basis of foremost physiognomics, which has been completely new in Polish topographical cartography. A new functional category was introduced - that of "public buildings", which were marked as residential buildings on the military map $^{3}$ (Zasady redakcji ... 1999). The share of functional characteristics is much larger on this map than on the military map $-52 \%$ in comparison with $41 \%$.

The concept of the map developed on the basis of DBTO10k was modelled on the concept of a 1:10,000 map in the "1992" coordinate system, and the changes introduced to the "1992" map are relatively small. The term "non-residential building", which was too generic, has been replaced with a more specific "public building", sewage treatment plant symbol was replaced it with an explanatory abbreviation, and a content category "industrial and storage area" was added, which due to its close connection with industrial buildings can

\footnotetext{
${ }^{3}$ From the military point of view, public buildings can become a place for accommodation of the trops during military operations.
} 


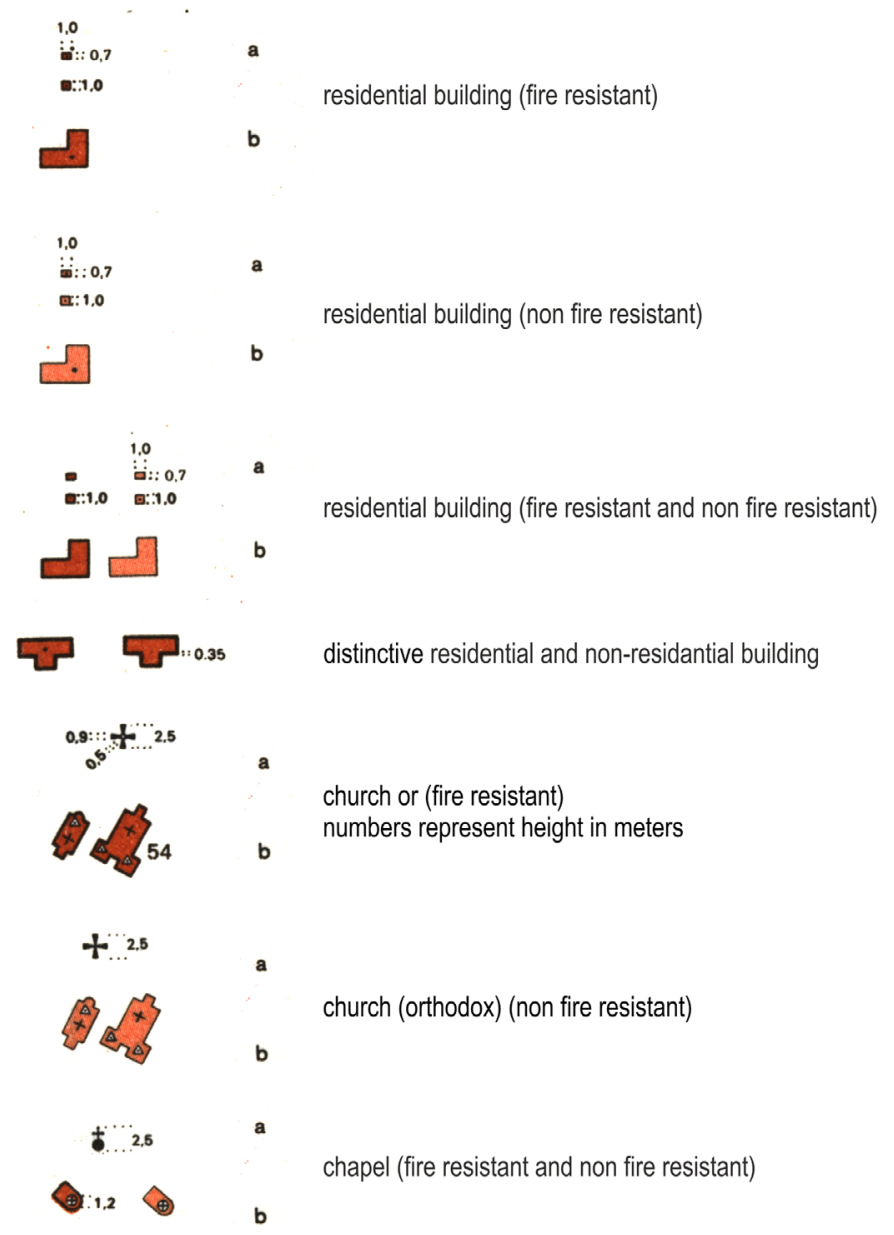

Fig. 1. A part of instructions for development of a military map at the scale of 1:10,000: a - symbols of objects that cannot be represented on the map's scale, $b$ - symbols of objects that can be depicted in this scale

be included in built-up areas (fig. 3) (Rozporządzenie... 2011). The share of functional characteristics is slightly larger in this case than on the 1992 coordinate system map and amounts to $54 \%$.

\section{Maps at the scale of $1: 25,000$}

While on 1:10,000 maps the characterisation of the built-up area consists in defining the characteristics of individual buildings (except for industrial and warehousing areas on the DBTO10k map), there is a new generalized conceptual category of "built-up areas" used on maps with the scale of $1: 25,000$ or smaller. Identification of built-up areas provides additional physiognomic information - it is a sign that in these areas buildings are located so close together that they cannot be represented on the map as individual objects ${ }^{4}$. On the military 1:25,000 map, built-up areas are defined

\footnotetext{
${ }^{4}$ However, it should be noted that this information is not completely unambiguous, because either quantitative generalization (selection of buildings) or conceptual generalization is typically used in practice (symbols of individual buildings are replaced with areal symbol indicating the built-up area) to depict medium-level buildings density on medium- and small-scale topographic maps.
} 


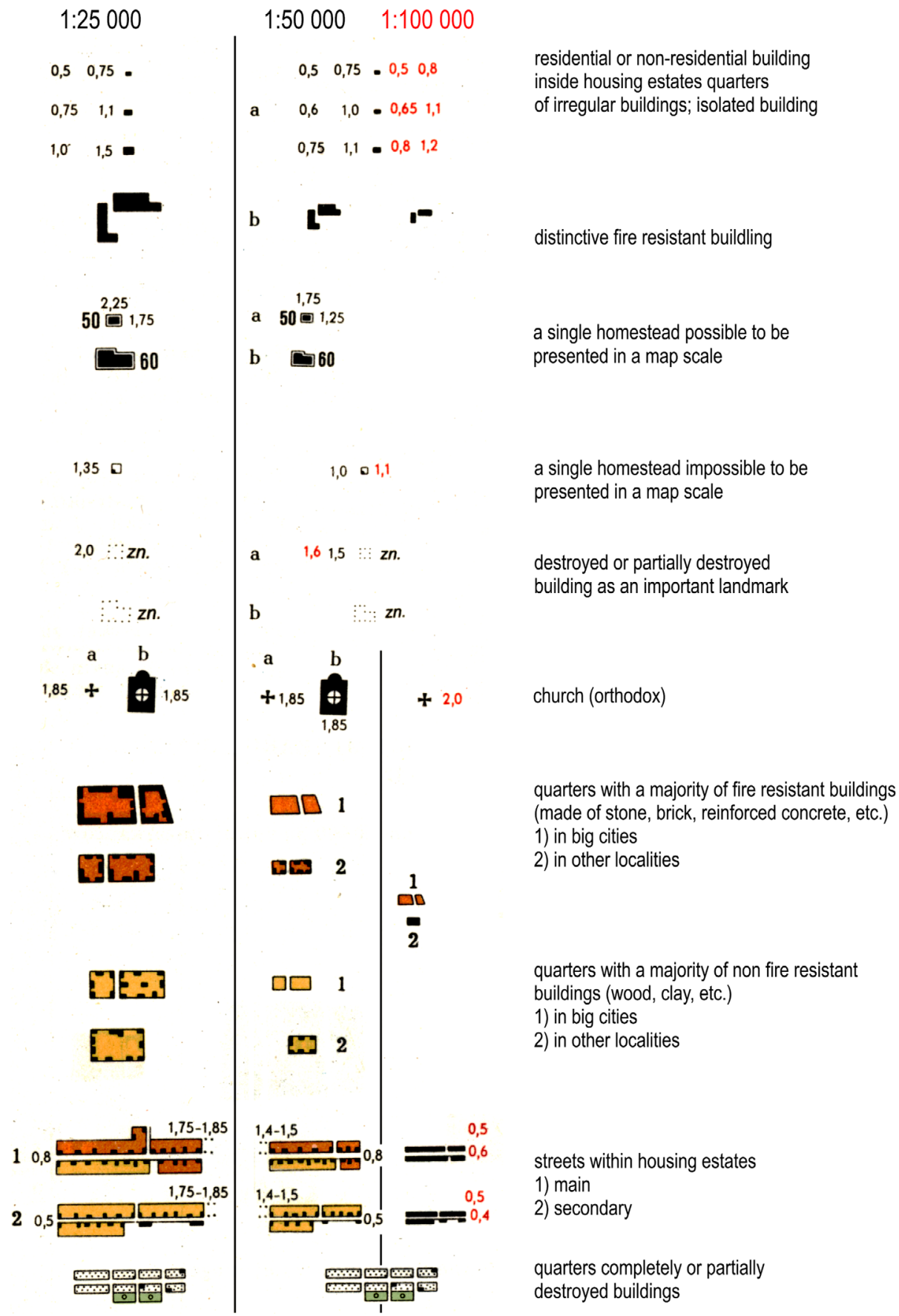

Fig. 2. A part of instructions for development of military maps at the scales of 1:25,000, 1:50,000 and 1:100,000: $a$ - symbols of objects that cannot be represented on the map's scale, $b$ - symbols of objects that can be depicted at this scale 
with three physiognomic characteristics: fire-resistance, lack of fire resistance and degree of destruction of buildings (fig. 2). As far as buildings are concerned, the fire-resistance characteristic, which is widely used on the military 1:10,000 map, applies only to distinctive buildings, which, in comaprison with this map, limited the number of building characteristics from thirty-nine to thirty-one. What is more, the military $1: 25,000$ map does identify residential buildings, which results in the lack of functional characteristics of the vast majority of buildings in cities. In rural areas, both on 1:25,000 maps and on maps with smaller scales $(1: 50,000$ and $1: 100,000)$, this characteristic is obtained by introducing the symbol of a single farm (Wzory i objaśnienia... 1986). Despite the abandonment of the fire resistance criterion, the share of the physiognomic features of buildings is only slightly smaller on the above-mentioned map than on the military $1: 10,000$ map and amounts to $58 \%$.

On the 1:25,000 map developed on the basis of DBTO10k, two areal symbols were used for the presentation of built-up areas - one for the afore-mentioned industrial and warehousing area and another for the area developed for single family homesteads. Symbols of all residential buildings and selected commercial buildings are presented on the aeral symbols. Additionally, the presentation and characteristics of the buildings depicted on this map are very similar to those presented on the 1:10,000 map of the Head Office of Geodesy and Cartography (HOGC), the only difference is the fact that the HOGC map contains also information about high-rise buildings. The share of functional characteristics presented on this map is almost the same as on the 1:10,000 map developed on the basis of DBTO and amounts to $53 \%$.

\section{Maps at the scale of $1: 50,000$}

The method and scope of characterization of built-up area presented on the military $1: 50,000$ map is almost identical to the one used on the military 1:25,000 map. The only new characteristic - one which aplies not to built-up areas per se, but to individual localities - consists in the use of different colours for presentation of built-up areas in localities which are classified as large cities, that is, ones with more than 50,000 inhabitants (orange colour), and for identification of those areas in smaller localities (yellow colour). As was the case with other military maps, the share of physiognomic characteristics is much larger than that of functional characteristics and amounts to $59 \%$.

The most important difference between the $1: 50,000$ map in the "1992" coordinate system and the military map of the same scale is the fact that built-up areas are distinguished on the basis of the size and density of buildings, which results in creation of the following categories: compact multi-family residential development, dense multifamily residential development and dense single family residential development, and at the same time the "1992" coordinate system map contains no information on fire resistance and distinctive buildings. The "1992" coordinate system map includes also more information on the function of buildings and distinguishes not only between residential and commercial buildings, but also industrial and public ones. The above-mentioned identification fo single farms on military maps applied only to farms which are possible to depict in a given scale. Inclusion of a separate symbol for summer houses is also worth noting (Zasady redakcji..., 1996). In contrast to the military map of the same scale, the characteristics related to functions of buildings are more numerous on the "1992" coordinate system map (56\% of the total number of characteristics).

The concept of presentation of buildings on the $1: 50,000$ map based on the DBTO10k is not much different from the one used on the "1992" coordinate system map of the same scale. The only difference is the lack of symbols of summer houses and individual farms presented in accordance with the scale of the map. From the point of view of building characteristics, it is important to note that this map has a separate symbol for commercial buildings, which on the 1:50,000 map developed in the "1992" coordinate system are represented with the same symbol as residential buildings. The share of characteristics related to functions of buildings is almost the same as on this map as on the "1992" coordinate system map and amounts to $57 \%$.

\section{Maps at the scale of $1: 100,000$}

The 1:100,000 military map, in comparison to the $1: 50,000$ military map, the issue of fire 


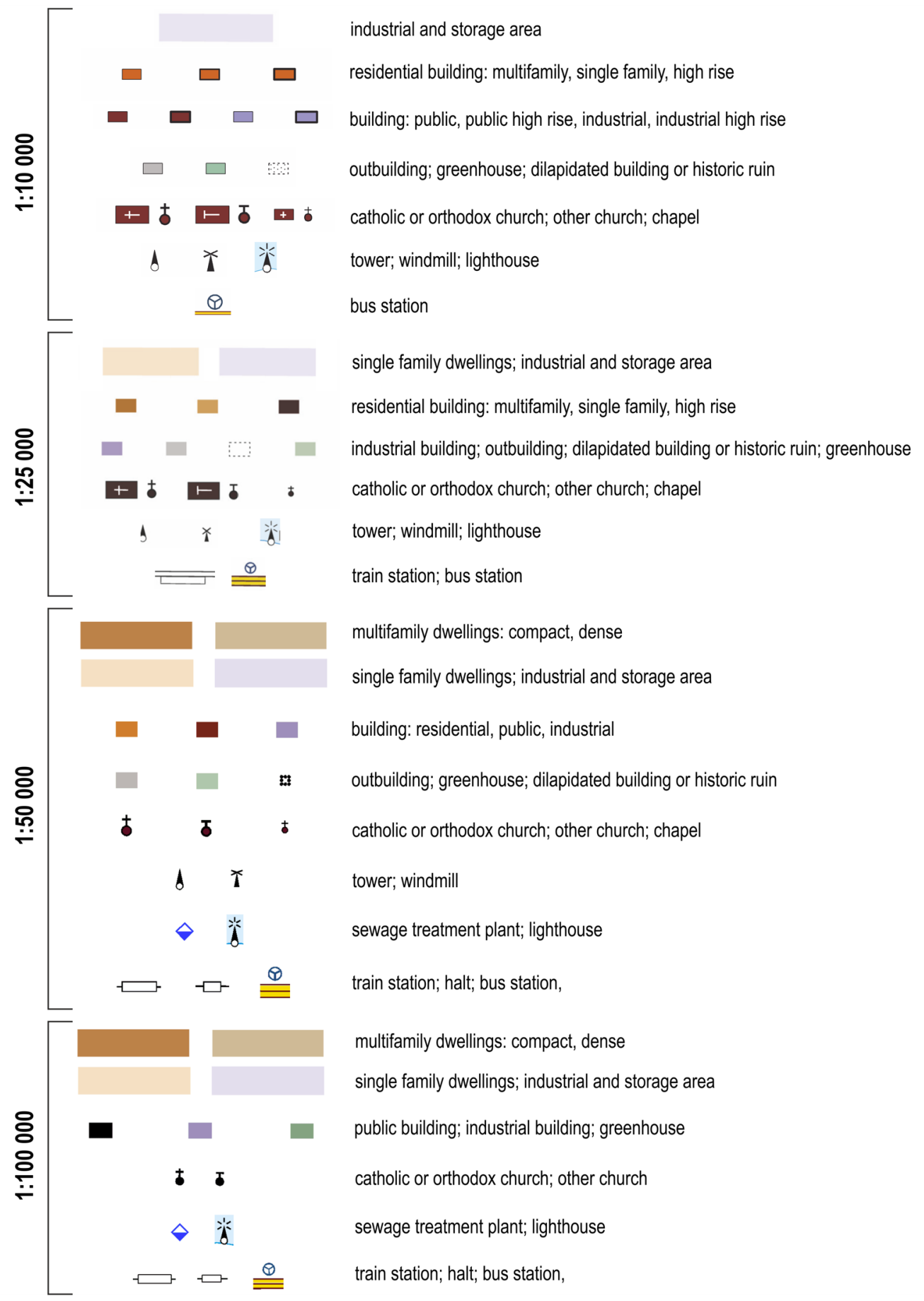

Fig. 3. Parts of legends of topographic maps developed on the basis of DBTO10k 
resistance is completely omitted, both in respect of the distinctive buildings and built-up areas in general. All other characteristics remain unchanged, including the different presentation of built-up areas in localities with populations exceeding and not exceeding 50,000. The predominance of physiognomic characteristics of buildings over their functional characteristics ( $54 \%$ vs. $46 \%$ ) is less noticeable on this map than its is on larger-scale military maps.

The 1:100,000 map created on the basis of DBTO10k, in comparison to the 1:50,000 map from the same series, contains a smaller number of distinctions concerning built-up areas (fourteen instead of twenty) and less characteristics of said area (twenty-three instead of thrity). Individual residential buildings are no longer represented with separate symbols, and commercial buildings are represented with the same symbol as industrial buildings. Dilapidated buildings, towers and windmills are also no longer represented on the map. Still, diversification of residential housing on the basis of building size and density (compact multifamily, dense multifamily, and dense single family residential development) (fig. 3).

\section{The Quartermaster's Map at the scale of $1: 126,000$}

Due to the relatively small scale of the map, the vast majority of buildings could be presented with the symbol of built-up areas (grey pattern), with symbols of individual buildings added on this background. What is more, areas within Warsaw with the highest building density were represented with a separate symbol. Symbols of individual houses include separate symbols for buildings which serve significant functions. Industrial buildings (brick-yards, sawmills, hameries, mills and windmills) have the highest number of indications, followed by service buildings (inns, post offices, telegraphs), buildings performing administrative functions (forester's lodges, customs houses) and religious buildings (churches, chapels). Five functional types of buildings (probably considered to be the most important in the landscape) were divided into two categories: wooden and brick buildings. These five types are: churches, chapels, inns, mills and windmills (fig. 4). Functional characteristics of buildings represent well over half $(62 \%)$ of all characteristics.

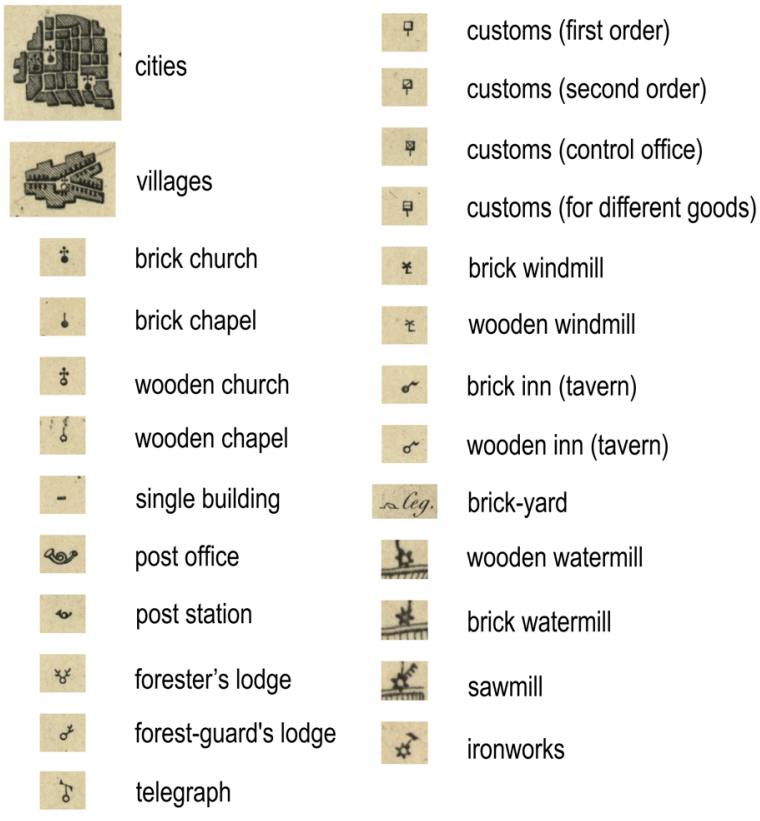

Fig. 4. A part of a legend of the Quartermaster's Map 


\section{1:25,000 and 1:100,000 maps of the Polish Military Geographical Institute}

Despite the large scale difference, the range of characteristics presented on the 1:25,000 and $1: 100,000$ maps is basically identical, and they differ mainly in the degree of quantitative and graphical generalization. Additionally, both maps differ in the manner of depicting the high-density build-up areas. It is shown in a dark grey pattern on the 1:25,000 map, and in black on the 1:100,000, just like individual buildings (fig. 5). Both maps include 21 categories of built-up area-related content and 29 characteristics of said area. When compared to the Quartermaster's Map, the MGI maps lack distinction between wooden and brick buildings in some categories of buildings, while their functional characteristics of buildings are more diversified. There are five types of functions of buildings: industrial (power plants, water mills, windmills, wood tar works), service (inns, hostels), administrative (forest offices, forester's lodges, forester-guard lodges), religious (churches, chapels), transport (railway stations, lighthouses, railway watchmen's booths) (fig. 6). Functional characteristics of the built-up area represent $55 \%$ of all of its characteristics.

\section{Characteristics of localities and parts thereof}

Topographic maps include not only information on characteristics of buildings and built-up
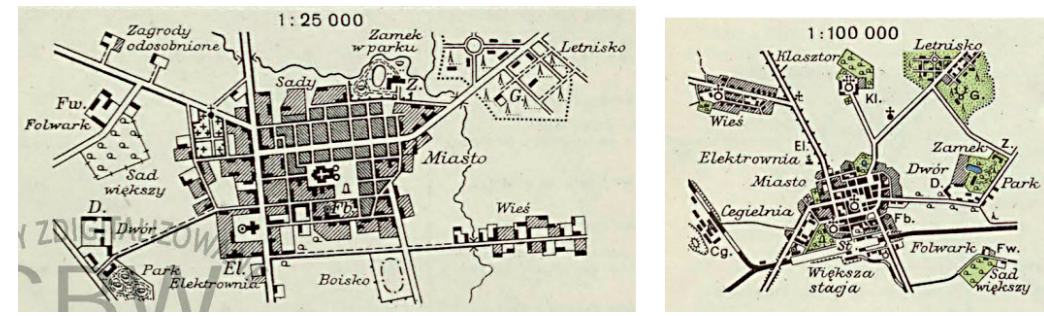

Fig. 5. Built-up areas on the maps of the Polish Military Geographical Institute

\begin{tabular}{|c|c|}
\hline 艺 (苍) & church with two towers (from far visible) \\
\hline б (あ) & church with one tower (from far visible) \\
\hline$\delta$ & non-Christian temple \\
\hline t & chapel \\
\hline & forest office \\
\hline $\begin{array}{l}\text { V } \\
\text { G. } \\
\text { G. }\end{array}$ & forester's lodge \\
\hline & forester-guard's lodge \\
\hline Kr.(Rest.) & tavern (restaurant) \\
\hline rSchr. & maintained shelter \\
\hline - Schr. & unmaintained shelter \\
\hline LEI. & power plant \\
\hline BR. $\sigma$ R. & ruin, historical ruin \\
\hline * & watermill \\
\hline$x(\underline{x})$ & windmill (from far visible) \\
\hline
\end{tabular}

Fig. 6. A part of a legend of a topographic map at the scale of 1:100,000, published by the Polish Military Geographical Institute areas, but also selected important features of individual localities such as cities, towns, villages or settlements and parts thereof. Names are the most important of these characteristics. Names of all localities are placed on 1:10,000 and generally also 1:25,000 maps. 1:50,000 maps omit the names of smallest ones, especially those with fragmented development, in the case of 1:100,000 maps, the share of omitted names can even amount to a few percent in some areas of Poland (W. Ostrowski, P. Kowalski 2004). The use of different tapefaces and text sizes for the names of localities shows the most important qualitative and quantitative characteristics of each locality, and, to a much lesser extent, their individual sections.

On all of the analysed maps, the names of towns and cities, and their individual sections, are written in majalcule, while the names of villages and, on the MGI maps, also the names of other settlements, are given in regular text. 
On the Quartermaster's Map, the names of the capitals of guberniyas and oblasts, as well as small localities were depicted on the map, using differnt letter size and slightly different typeface. On the MGI maps, the inscriptions vary depending on the size of the locality, with six size classes of cities and towns defined on the basis of the number of inhabitants, and five size classes of villages on the basis of the number of houses. It may be surprising to note that completely different size classes are used on the 1:25,000 map (over 200, 40-200, 20-40, 4-20 and below 4 houses) and on the 1:100,000 one (over 150, 40-150, 30-40, 10-30, and less than 10 houses). Most of the maps published after World War II determined their size classes on the basis of the number of inhabitants: military maps had seven size classes for cities and towns, two size classes for urban-like settlements and four for villages, whereas civilian maps had eight size classes for cities and towns, and six classes for villages. Only earlier editions of military maps had sizes of village determined on the basis of the number of houses.

As already mentioned, some editions of $1: 25,000,1: 50,000$ and $1: 100,000$ military maps distinguish between cities and towns with populations with more and less than 50,000 inhabitants by using different colours for relavant built-up areas.

Both civil and military maps issued after the Second World War include under the names of localities information on their administrative functions and statuses (e.g. seats of voivodeship, poviat, and commune authorities).

The form and manner of presentation of localities' names provide not only information on their sizes and functions, but also information on the spatial range with dispersed development or ones which consist of several isolated sections. It is particularly important in relation to the MGI maps and 1:25,000, 1:50,000 and $1: 100,000$ military maps, as well as the Quartermaster's Map, where municipal administrative boundaries are not shown.

The determination of the territorial range of the locality with a dispersed development or several isolated sections allows for using socalled additional names, which constitute repetitions of the main name of a given village and are placed near the sections which are located apart from each other. This method is most often found on large scale maps $-1: 10,000$ and
1:25,000 maps, but also, though much less frequently, on $1: 100,000$ and $1: 126,000$ maps. On the MGI map, additional names of individual sections of localities were inserted into brackets.

\section{Summary}

The above-presented review of the ways of characterizing one of the most important elements of topographic map content can serve as a good illustration of the belief, shared by many scholars, that the map is not only an effect and a tool for exploring and analysing reality, but also a social product that allows us to recreate the way in which society conceptualised its knowledge about the surrounding space and determined which objects in said space were perceived as significant (W. Żyszkowska 2005). The period of two hundred years, which was considered in this analysis, is long enough for the analysis to reveal certain changes in perception, and thus also presentation of the cultural landscape whose typical components include buildings.

All the analysed maps present chapels and churches, divided into Christian and non-Christian ones, which results from the fact that they constitute particularly permanent and important elements of the cultural landscape. From all other elements of built-up areas, only windmills appear on all the maps, and in the last decades they represent only distinctive elements of landscape and ruins. From all the categories depicted on the nineteenth-century Quartermaster's Map, only the above-mentioned content elements, individual houses, built-up areas and high-density development areas remain on contemporary maps, which amounts to $30 \%$ of all the symbols used on the old map. More content elements of the $\mathrm{MGI}$ maps remained on contemporary maps (43\%).

A characteristic feature of the development of cartography in recent centuries is the increase in the importance of synthetic depictions and characteristics in comaprison to the analytical ones. We can also clearly observe this in relation to the characteristics of buildings. There are only two synthetic characteristics on the Quartermaster's Map and the MGI maps: built-up areas and high-density development areas (Quartermaster's Map), as well as areas of dense and disperse development (MGI maps). On modern smaller scale maps intended for 
civil use, there are seven such characteristics. In addition to the already mentioned types of buildings and industrial and warehousing areas, the maps contain symbols of public, industrial and commercial buildings. They enriched the physiognomic characteristics of both built-up areas and buildings.

It could be expected that the number of content categories or the number of characteristics should be larger on modern maps than on the old Quartermaster's Map or the MGI maps. It turns out, however, that these numbers are similar. The highest number of both content categories and characteristics was included on military maps developed after the Second
World War, and the lowest number can be found on BDOT10k-based maps (figs. 7 and 8). The 1:10,000 military map stands out among all the analysed maps, due to the inclusion of the aforementioned characteristics of fire resistance and lack thereof. It is worth noting that such characteristics (wooden and brick buildings) were, as already mentioned, widely used on the Quartermaster's Map, and they were not presented on the MGI interwar maps, although those maps were also developed by the military. It results from the fact that in the Kingdom of Poland, as in all of Russia, wooden buildings dominated outside large cities, and brick buildings definately stood out, which was

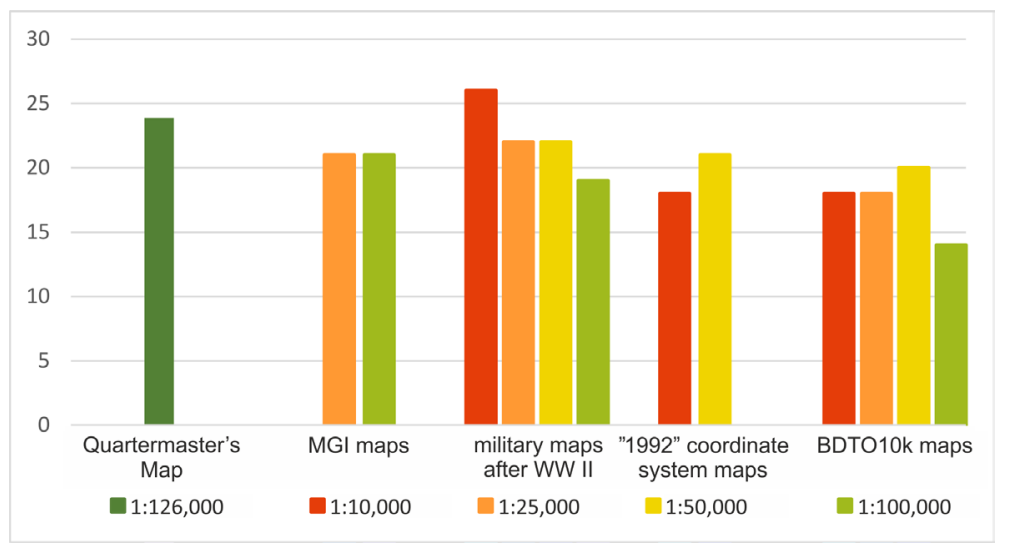

Fig. 7. Number of categories of content which belong to the built-up area

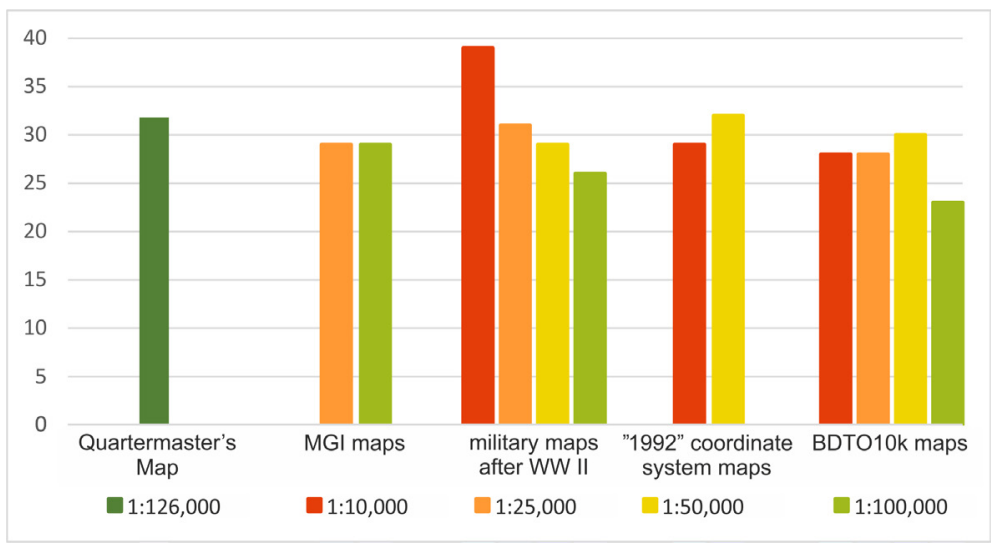

Fig. 8. Number of characteristics of built-up area 


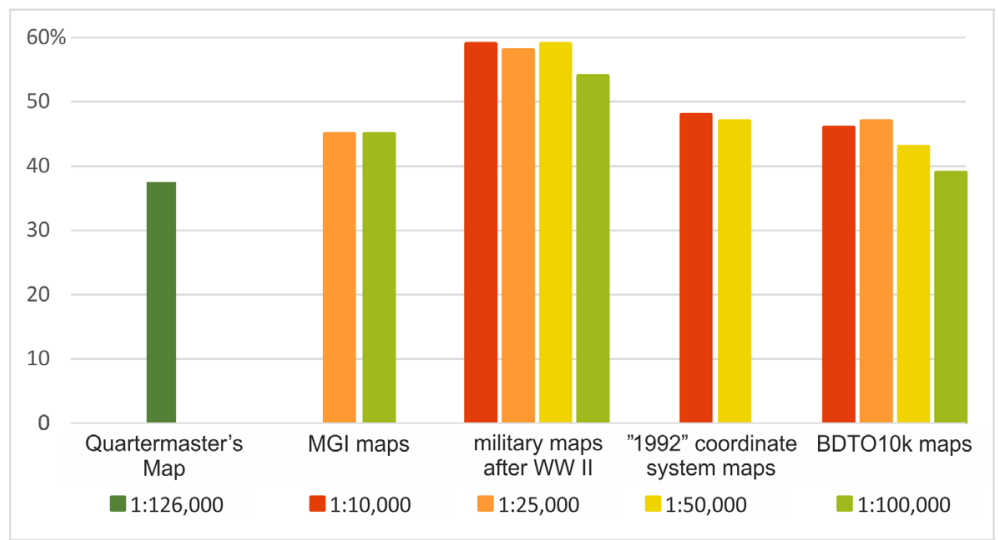

Fig. 9. Share of physiognomic characteristics in the overall number of characteristics of built-up area

important when it came to the army's orientation in the field. The Quartermaster's Map is, to a certain extent, an example of the 19th-century Russian topographical cartography, which was continued by topographical Soviet maps, and the concept of these maps was imposed on post-war Polish military cartography for political reasons. However, the interwar MGI maps were largely modeled on topographic German maps. In Germany, most buildings were made of bricks, so there was no need to mark individual brick buildings on maps.

The decrease in the number of content categories, which occurs in line with the reduction of scales of maps, is clearly visible on military maps issued after World War II and on the $1: 100,000$ map developed on the basis of DBTO10k. This number increases on 1:50,000 maps intended for civil use, which results from the introduction of new characteristics of built-up areas (fig. 7). Post-war civil and military maps clearly differ in the share of physiognomic and functional characteristics. On military maps issued after World War II, the share of physiognomic characteristics is much larger than that of functional characteristics, and at the same

\section{Literature}

Imhof E., 1936/37, Das Siedlungsbild in der Karte. „Mitteilungen der Geographisch-Ethnographischen Geselschaft Zurich" Bd. 37, pp. 17-86.

Liszewski S., 1978, Tereny miejskie, podział i klasyfikacja. „Acta Universitatis Lodziensis. Folia Geographica" Ser. II, no. 15, pp. 3-33. time by more than a dozen percentage points larger than on civil maps. Physiognomic characteristics have a much smaller share on the inter-war MGI maps than on the post-war military maps, and their share on the nineteenth-century Quartermaster's Map is even smaller (fig. 9). This is probably due to the fact that both of these maps took into account not only the military use, but also their wider use, e.g. in administration, and in the case of the MGI maps also in tourism.

Both of the analysed series of civil maps are distinguished primarily by their richer, in comparison to military maps, functional characteristics of buildings, in particular by distinguishing not only industrial buildings, but also public buildings, and on most maps based on BDOT10k also commercial buildings. The second characteristic feature of presentation of buildings on civil-use maps are characteristics of building density (multifamily, single family, compact, dense) on 1:50,000 and 1:100,000 maps and the capacity of residential buildings (multifamily and single family buildings) on larger-scale maps $(1: 10,000$ and $1: 25,000)$.
Neuman J., 1972, Wo liegt die Masstabsgrenze zwischen topographischen und chorographischen Karten? „Kartographische Nachrichten” Jg. 31, H. 2, pp. 47-52.

Ostrowski W., 2008, Semiotyczne podstawy projektowania map topograficznych na przykładzie pre- 
zentacji zabudowy. Warszawa: Wydawnictwo Uniwersytetu Warszawskiego.

Ostrowski W., Kowalski P., 2004, Zbieranie i opracowywanie nazw geograficznych. Przewodnik toponimiczny. Część III. Stosowanie i rozmieszczanie napisów na mapach. Warszawa: Główny Urząd Geodezji i Kartografii.

Rozporządzenie: Opis baz danych obiektów topograficznych i ogólnogeograficznych oraz standardy techniczne tworzenia map. Tom 1, „Dziennik Ustaw Rzeczypospolitej Polskiej”, 2011, Nr 279, poz. 1642.

Schmid D., 1987, Developments in the design of topographic maps in Federal Republic of Germany - activities and suggestions. „Nachrichten a.d. Karten- und Vermessungswesen" Series II, no. 46, pp. 139-164.

Schmid R., 1966, Die Entwicklung der neuen Topographischen Karte 1:50 000 aus der Deutschen Grundkarte 1:5000 (Generalisierung für eine Verkleinerung). In: Kartographische Generalisierung. Ergebnisse des 6. Arbeitskurses Niederdollendorf 1966. Mannheim: Bibliographisches Institut, pp. 119-134.

Wzory i objaśnienia znaków umownych i napisów stosowanych na mapach topograficznych 1:25 000, 1:50 000 i 1:100 000 (podane w skalach roboczych 1:20 000, 1:40 000 i 1:75 000), 1986. Warszawa: Ministerstwo Obrony Narodowej, Sztab Generalny Wojska Polskiego.
Wzory i objaśnienia znaków umownych i napisów stosowanych na mapach topograficznych w skalach 1:5000 i 1:10 000, 1989. Warszawa: Ministerstwo Gospodarki Przestrzennej i Budownictwa, Departament Geodezji, Kartografii i Gospodarki Gruntami.

Zasady redakcji mapy topograficznej w skali 1:50 000. Katalog znaków. Instrukcja techniczna, 1996. Collective elab.: W. Ostrowski (head of the team), J. Balcerzak, A. Czerny, A. Dziewulska, A. Kaczyński, J. Maj, B. Morawska, J. Siwek, B. Stolarczyk. Ministerstwo Gospodarki Przestrzennej i Budownictwa, Państwowa Służba Geodezyjna i Kartograficzna. Warszawa: Główny Geodeta Kraju.

Zasady redakcji mapy topograficznej w skali 1:10 000. Wzory znaków. Instrukcja techniczna, 1999. Wyd. drugie poprawione. Collective elab.: W. Ostrowski (head of the team), J. Balcerzak, J. Maj, M. Kacprzak. Główny Geodeta Kraju. Warszawa: Główny Urząd Geodezji i Kartografii.

Znaki i objaśnienia do map 1:25 000, 1:100 000 i 1:300 000. 1937. Warszawa: Wojskowy Instytut Geograficzny.

Żyszkowska W., 2005, Funkcje map w cywilizacji. In: Społeczna i edukacyjna rola kartografii w Polsce, XXXI Ogólnopolska Konferencja Kartograficzna, Warszawa, 20 i 21 października 2005. „Materiały Ogólnopolskich Konferencji Kartograficznych” T. 26, Warszawa, pp. 11-20. 